\title{
US-CHINA LAW REVIEW
}

VOL. 12

March 2015

NO. 3

\section{THE PYRAMID MODEL OF CRIMINALISTICS AND ITS BASIC PRINCIPLES}

\section{Csaba Fenyvesi*}

\begin{abstract}
The author-in the first part of his paper-outlines a model of the central questions, methodology, system of media, and the ultimate goal of criminalistics, by now a sophisticated, meticulous and diversified empirical science of facts. It is hoped that the model is presented in a simple form which is clear to everybody and can be used in theory, in everyday practice as well as in education. For purposes of diagrammatic representation, the shape of a pyramid, composed of 7-3-1 building blocks from bottom up, seems the most appropriate. The pyramid model can be called the 7-3-1, or simply 731, model. In the second part of his paper, the author talks about the basic principles of forensic science.
\end{abstract}

INTRODUCTION

I. THE PYRAMID MODEL OF CRIMINALISTICS ..........................................234

II. BASIC PRINCIPLES OF FORENSIC SCIENCE...........................................2239

A. Fundamental Questions in Criminalistics ............................... 240

B. Traces and/or Material Remains Are Left Behind in Every

Criminal Act.

C. The Uniqueness and Identifiability of Persons and Physical Objects

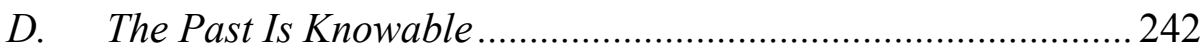

CONCLUSION. 243

\section{INTRODUCTION}

A scientist is driven by his curiosity. He will ask questions and search for possible answers, ultimately the correct answer to each, sometimes during his entire life. To formulate questions, good questions, that is, are one of the most difficult tasks.

According to a (slightly edited version of a Szekler) anecdote, a

\footnotetext{
${ }^{*}$ Mr., Dr. univ. ec., Ph.D., Dr. habil., Associate Professor, Criminal Procedure and Folrensic Science Department, Law Faculty, University of Pécs. Research fields: Justizmord Cases, Reasons, Line-up, Identity Parade Process.
} 
stranger from the countryside visiting Budapest for the first time turns to a local asking "Could you tell me where Parliament Building is?" The local succinctly answers "Yes, I could" and walks on.

A researcher's questions need to be simple, clear and to the point, which, therefore, call for fair and square answers, possibly useful for others too. Forensic science formulated its essential questions over a hundred years ago. Answering them faithfully can provide the foundation for establishing the facts of a case in court and for the state to enforce its criminal law claims.

To put it slightly different, the seven basic questions have been raised to the level of fundamental principles, as the principled claim can be made that if one knows the exact answers in connection with a criminal act, then one knows the past events and is able to derive correct legal inferences from the facts. ${ }^{1}$ As the wisdom of Roman law holds, da mihi factum, dabo tibi ius, that is, "give me the fact(s), I'll give you the law". Questions of fact always take precedence over issues of law. ${ }^{2}$ One cannot "do law" and categorize a state of affairs without an accurate knowledge of the facts. (This holds not only for facts of the case in criminal law but more generally in all branches of law and all aspects of the legal profession.)

The reverse of the above reasoning also holds. If you do not know the answers to the questions, then you do not know the past and cannot formulate the facts of the case, and consequently, you cannot make legal category judgments either. As the author frequently says, one always has to "do the facts" first before "doing the law".

\section{THE Pyramid MODEL OF CRIMINALISTICS}

In the first part of the author's paper, the author will outline a model of the central questions, methodology, system of media, and the ultimate goal of criminalistics, by now a sophisticated, meticulous and diversified empirical science of facts. It is hoped that the model is presented in a simple form which is clear to everybody and can be used in theory, in everyday practice as well as in education.

For purposes of diagrammatic representation, the shape of a pyramid, composed of 7-3-1 building blocks from bottom up, seems the most appropriate. The pyramid model can be called the 7-3-1, or simply 731 ,

\footnotetext{
${ }^{1}$ Subsection (1) of Section 75 of the Criminal Proceedings Act asserts that "Evidence shall cover the facts which are relevant to the application of criminal statutes and legal regulations on criminal proceedings. The objective of gathering evidence shall be the thorough and complete elucidation of the true facts."

${ }^{2}$ As is also suggested by the title of a monograph by Árpád Erdei, Tény és jog a szakvéleményben (Facts and law in expert opinions) (KJK, Budapest 1987).
} 
model. Consider the diagram below.

The Pyramid Model of Criminalistics

A KRIVINALISZTIKA PIRAMIS MODELLJE

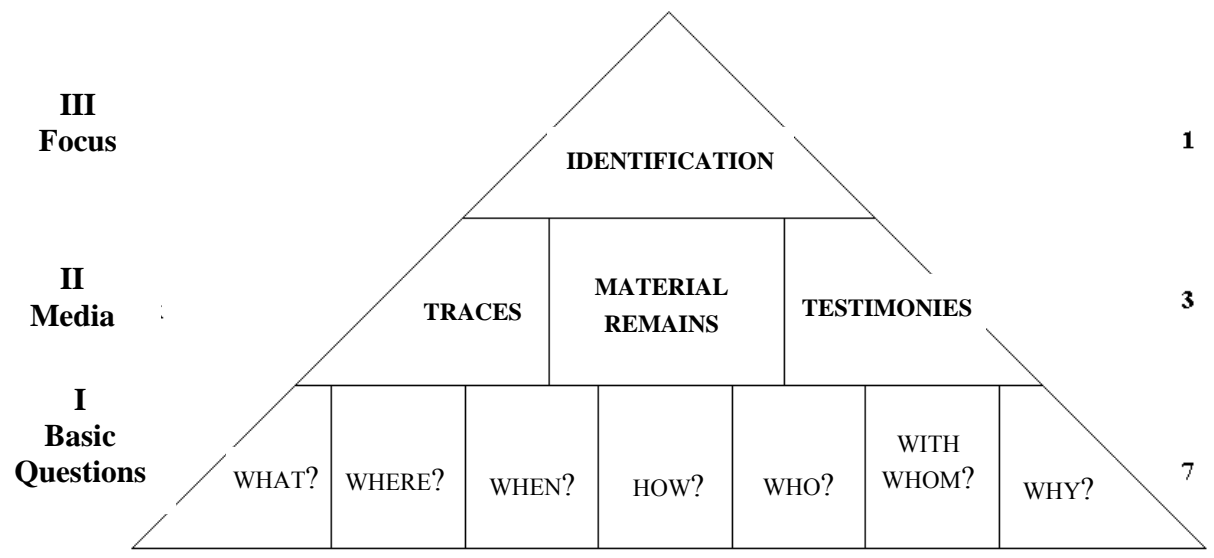

Level I: PRINCIPAL QUESTIONS IN CRIMINALISTICS. At the bottom of the pyramid, as in the physical world, we find the most solid basic building blocks - the seven basic questions, already consolidated in the technical literature: WHAT? WHERE? WHEN? HOW? WHO? WITH WHOM? and WHY? (I/1-2-3-4-5-6-7).

Some theoreticians in forensic science have expanded these questions up to 12 , adding, for example, to whose gravamen? with what means? for what reason or purpose? causing what damage? etc. It may be noted that question No. 6, With whom?, need not be asked, as if more than one person was involved, then, according to the rules of English grammar, the answer to question No. 5, Who?, will contain the names of accomplices too. Nevertheless, the "7 W-questions" formula, adopted here, has become a conventionally and internationally accepted concept in forensic science (as well as the practice of criminalistics).

It is no coincidence that the first among the seven short questions is "WHAT?", as the answer to the essential question "What happened?" not only gives the impetus but also decides whether the authorities need to start a criminal investigation at all or instead proceed to take public administration, labour, etc. measures, to mention only a few of countless alternative possibilities and areas. If the answer to that question is "a criminal act", that will immediately decide about the personnel to be deployed, the expertise required, methods and devices to be employed, and some further basic questions will immediately become sharper. The word "immediately" receives special emphasis here, as the question of time 
becomes important instantly not only because of the need for a speedy investigation and the rapid uncovering of the facts but also because the "WHEN?" question comes to the foreground. The triplet of questions, ${ }^{3}$ WHERE-WHEN-HOW, begin to compete for priority as soon as the "WHAT?" question is answered. They arise almost simultaneously and urgently, demanding accurate answers in the shortest possible time, because without them the rest of the questions (WHO, WITH WHOM?) cannot be explored.

Now it seems appropriate to skip the boxes on the second level of the pyramid and move directly to the single block at the top, on level III.

Level III: THE FOCUS OF CRIMINALISTICS

This represents the point of focus, the goal of the entire struggle to learn about the past, the target of all the basic questions every time and in every detail, namely: IDENTIFICATION.

This goal, printed in huge letters in red above the chalk board on a wall in the "forensic laboratory" 4 in Pécs, used to remind everybody of what constantly guides (and needs to guide) criminalists in each move in their search for noise-free answers to the seven questions.

We identify the type of act — whether it was a criminal act, or perhaps an accident, a natural disaster or self-violence.

If (and only if) we are dealing with a criminal act, we may move on from the primary question to the rest of the questions, that is, we need to identify the scene or scenes, we need to identify the time and manner of the commission of the act, its motive (and sometimes also the aggrieved party), ${ }^{5}$ and finally (all of) the perpetrator(s).

How do we get from the basic questions at the bottom to the top of the pyramid? In other words, what are the methods and instruments of identification? The answers can be worked out from the three blocks on Level II, the intermediate level of the pyramid.

Level II: CRIMINALISTICAL INSTRUMENTS (WAYS and PATHS)

The terms "ways" and "paths" suggest that it is through or along them that we work our way from clarifying and ascertaining data relevant to the

\footnotetext{
${ }^{3}$ Not surprisingly, they play a central role in the monograph by László Pusztai titled Szemle a büntetőeljárásban (Survey in the criminal procedure) (KJK, Budapest) in connection with the crime scene.

${ }^{4}$ For more detail, see Csongor Herke, Kriminalisztikai laboratórium Pécsett (Forensic laboratory in Pécs), 7-8 BelügYI SzEMLE 153 (1998), and A kriminalisztika mint tudományág és mint egyetemi tantárgy (Criminalistics as a science and as a university subject), 2 MAGYAR TUDOMÁNY 196-201 (2003).

${ }^{5}$ For more detail on this, see Miklós Angyal, A személyazonositási eljárások jellemzői (Characteristics of personal identification procedures), MS, PhD dissertation (Pécs 2014).
} 
main questions at the bottom through identification, which is, giving straight answers to them at the top. We can call them the media or "mediators", which deliver all the necessary information provided that you know how to "talk to them" or understand them. ${ }^{6}$ The set of all possible paths, instruments and media can be divided into three main groups-TRACES, MATERIAL REMAINS and TESTIMONIES (II/1-2-3).

An overview of our demonstration system, the kinds of evidence specified in criminal procedure law (demonstration procedures), ${ }^{7}$ makes it apparent that the means of demonstration worked out in theory or employed in practice (instruments of demonstration) fall into one of the three categories. Witness testimonies, accused testimonies, hearings at the scene, facial recognition tests, testimonies at confrontations ${ }^{8}$ and polygraph tests ${ }^{9}$ all fall within the category of testimonies, which may also include experts' opinions as well as their (parallel) hearings. The list is not exhaustive. We must add that expert opinions overlap with traces and material remains, as the former chiefly testifies about results from studying and identifying the latter, which they may find identical or otherwise. ${ }^{10}$

Physical evidence ${ }^{11}$ emerging from surveys is, in reality, traces and material remains or their causers or carriers. (Consider, for example, the means of perpetration, the thing(s) affected by the criminal act or things that come to exist as a consequence of a criminal act.)

Documentary evidence, too, is a carrier of traces or material remains, and frequently appears in the form of expert opinions. In addition, it also "testifies", as it presents the statements it contains. ${ }^{12}$

Evidence obtained in a secret manner can also be classified into the

\footnotetext{
${ }^{6}$ I feel justified in characterizing criminalistics as the gradual process of expanding and improving pieces of circumstantial evidence. It is a combination of science and art, comprising intellectual as well as practical activities.

${ }^{7}$ The terminology (procedures within a procedure) is considered inappropriate. For more detail, see Cs. Fenyvesi, F. Tremmel and Cs. Herke, Új magyar büntetöeljárás (New Hungarian Criminal Procedure), Dialóg Campus Kiadó, Budapest-Pécs 210-301 (2004).

${ }^{8}$ Cf. Dániel Antal, Confrontation as a Special Criminalistic Method. In POKROKY v Kriminalistike 2011 EU SEC II/B 68-83 (Jozef Metenko, Sona Masnicová and Magdaléna Krajníková eds., Akadémia Policajného zboru v Bratislave 2011).

${ }^{9}$ Cf. Árpád Budaházi, Poligráf a büntetöeljárásban (The Polygraph in the Criminal Procedure), 12 BELÜGYI SZEMLE 104-117 (2011).

${ }^{10}$ For more detail on this, see Jáde Várdai Viktória, Szakértő, bíró vagy tanú? (Expert, Judge, or Witness?) In JoG És ÁlLAM (KRE-ÁJK 2012, to appear).

${ }^{11}$ A thorough (comparative) monograph was written on this by Imre Kertész, A tárgyai bizonyitékok elmélete a büntetöeljárási jog és a kriminalisztika tudományában (The Theory of Physical Evidence in Criminal Procedure Law and Forensic Science) (KJK, Budapest 1972).

${ }^{12}$ Cf. Csenge Tóth, Bence Mészáros and Csaba Fenyvesi, Examinarea Documentelor Suspecte (Questioned Document Examination) Revista De Criminologie, De Criminalistica Si De Penologie, Societatea Romana De Criminologie Si Se Criminalistica 152-160 (Cluj Napoca, Roumania, Mar. 2010).
} 
three categories, as

(a) it contains statements, assertions, communications, such as, for example, intercepted conversations, correspondence, computer data, ${ }^{13}$ which, although appear in documentary format in the circle of evidence in accordance with procedural rules, may be considered testimonies ${ }^{14}$ or traces from a forensic perspective;

(b) it delivers physical evidence, traces or material remains ${ }^{15}$ (any drug is material remains in a forensic sense), for example, in the course of secret searches or pseudo-purchases.

The order of boxes on level II is not arbitrary. Traces ${ }^{16}$ and material remains are intentionally mentioned first and second, respectively, preceding testimonies. This is for the theoretical and practical reason that traces and material remains are "incorruptible witnesses", that is, according to modern theories of evidence and criminalistics, their validity surpasses that of personal testimonies (compare the level of validity of dactyloscopy or individual identification by DNA samples), which are often distorted, especially in the circle of witnesses and suspects. ${ }^{17}$ The idea accords well

\footnotetext{
${ }^{13}$ For more detail on this, see Pál Déri, Korszerü nyomozás - integrált bünüldözés (Modern Investigation -Integrated Criminal Investigation), BM TANULMÁNYI ÉS PROPAGANDA CSOPORTFÖNÖKSÉG (Budapest 1976); Pál Déri and Attila Budai, Korszerü bünüldözés (Modern Criminal Investigation), ORFK (Budapest 1991).

${ }^{14} \mathrm{Cf}$. Bence Mészáros, Fedett nyomozás a bünüldözésben (Undercover Investigations in Criminal Investigation), $\mathrm{PhD}$ dissertation (PTE-ÁJK Doktori Iskola, Pécs 2011).

${ }^{15}$ For more detail on odor as material remains, see Orsolya Horváth, A kriminalisztikai szagazonositás jelene és jövöje (The Present and Future of Forensic Odor Identification), MS with special recognition at XXX, OTDK (Students' Research Conference) (Pécs, PTE ÁJK, April 20, 2011).

${ }^{16}$ On the significance of traces in criminalistics and demonstration, see Géza Katona, A nyomok azonositási vizsgálata (Identificational Study of Traces) (KJK, Budapest 1965), and Bizonyítási eszközök a XVIII-XIX, században (Instruments of Demonstration in the 18th and 19th Centuries). A kriminalisztika magyarországi elözményei (Antecedents to Criminalistics in Hungary) (KJK, Budapest 1977).

${ }^{17}$ On factors influencing witness testimonies, see Gyula Bíró, Kriminalisztika (Criminalistics), DeBreCENI EgYetem ÁJK- LícIUM-ART KöNYVKIADÓ KFT 116-138 (Debrecen 2010); Balázs Elek, $A$ vallomás befolyásolásaa a büntetöeljárásban (Influencing Testimonies in the Criminal Procedure), Tóтн KFT (Debrecen 2008); Imre Kertész A kihallgatási taktika lélektani alapjai (Psychological Foundations of Interrogation Tactics) (KJK, Budapest 1965); József Molnár, A kriminalisztika tudománya (Forensic Science). A tanú és a terhelt kihallgatásáról (Hearing the witness and the accused). In Kriminológiai és Kriminalisztikai Tanulmányok (Studies in criminology and criminalistics), XXXVI 199-245 (OKRi, Budapest 1999); Lajos Nagy, Tanúbizonyitás a büntetöperben (Witness Demonstration in the Criminal Case) (KJK, Budapest 1966); Mihály Tóth, A terhelt védekezési szabadságának tartalma és konfliktusai, különösen a nyomozásban (The Content of and Conflicts in the Freedom of Defense of the Accused, Especially in Investigations), $\mathrm{PhD}$ dissertation (Budapest 1988); Eszter Szücs, A sértettgondozó és a sértettgondozás fogalma, kialakulása, szerepe a kriminalisztikában (The Caretaker of the Accused and the Concept, Its Evolution and Its Role in Criminalistics), RENDÉSZETI SZEMLE 124-145 (Apr., 2010); Flórián Tremmel, Csaba Fenyvesi and Csongor Herke, Kriminalisztika Tankönyv és Atlasz (Textbook and Atlas in Criminalistics), DialóG-CAmPus Kiadó (Budapest-Pécs 2005, 2009); KRIMINALISZTIKA (CRIMINALISTCS)
} 
with tendencies in criminalistics in the 21 st century, one of which happens to assert precisely the primacy of forensic techniques over forensic tactics. ${ }^{18}$ The desire is to raise forensic techniques to the level of scientific knowledge, ${ }^{19}$ characterized by outstanding validity, ${ }^{20}$ as opposed to the, albeit non-malevolent, inaccuracy and unpredictability of testimonies.

\section{BASIC PRINCIPLES OF FORENSIC SCIENCE}

At first sight, it may appear that the declaration of the primacy of criminal techniques is some kind of principle, which arguably raises the metatheoretical question of whether there exist any fundamental principles in forensic science at all.

Over the past few hundreds years, in a considerable number of branches of statutory law (e.g., criminal procedure law), some general, leading ideas have been formulated, which, especially in procedural codes, right from the very beginning, mark the path to be followed, and never to be abandoned, in the application of law throughout the entire procedure. As criminalistics is not jurisprudence but an (applied) empirical science, it has no code of conduct. Therefore, textbooks in forensic science do not open with a chapter on its codified principles. Nevertheless, my view is that there are a few foundation stones which may offer some principled guidance for criminalists in their efforts to uncover past states of affairs in an accurate manner, which makes the undistorted detection of the facts of the past possible. The author will, non-exhaustively, discuss some of these below.

(László Vargha ed., Tankönyvkiadó, Budapest 1980); Csaba Fenyvesi, Szembesités. Szemtől szembe a bünügyekben (Confrontation: Face to Face in Criminal Cases), DiAlóG-CAMPUS KIADÓ (BudapestPécs 2008); Flórián Tremmel, Bizonyitékok a büntetöeljárásban (Evidence in the Criminal Procedure), Dialóg CAMPUS KIADÓ (Budapest-Pécs 2006); KRIMINALISZTIKA ÁltaláNOS RÉSZ (CRIMINALISTICS General PART) (László Viski ed., Budapest 1961); Kube, E.-Störzer, H.U.-Timm, K.J.: Kriminalistik, I-II. (Handbuch für Praxis und Wissenschaft) (Stuttgart 1992); E. Bócz, E.: Kriminalisztika, I-II. (Criminalistics) BM Duna Kiadó (Budapest 2004); Campbell, A.: Forensic Science (Chelsea House Publishers, Philadelphia 2000); Metenko, J.: Kriminalisticka taktika, Akadémia Policajného Zboru v Bratislave (Bratislava 2012); Most recently, Lilla Luca Huba, Deception detection - avagy a megtévesztés felderitése és az igazságügyi öszinteségvizsgálat a büntetöeljárásban (Deception Detection-Detecting Deception and Forensic Honesty Tests in the Criminal Procedure), MS, 3rd prize winner paper presented at XXX. OTDK (Students' research conference) (Pécs, PTE ÁJK, April 20, 2011).

${ }^{18}$ Some people in the world would like to test even the validity of testimonies that fall within the circle of forensic tactics with the help of natural sciences. For more on this, see Eszter Póczos, $A$ hazugságvizsgálat jövőképe (The Future of the Lie Detector), BELÜGYI SZEMLE 100-109 (May, 2006).

${ }^{19} \mathrm{Cf}$. József Orbán, A jog konvergenciája a természettudományok felé a Bayes-analízis apropóján (The Convergence of Law toward Science, Apropos of the Bayes-analysis), GLOSSA IURIDICA 42-46 (Jan., 2012).

${ }^{20}$ For more detail on this, see Csaba Fenyvesi, $A$ XXI. századi bünüldözés-tudomány nemzetközi tendenciái (International Tendencies in 21st-century Forensic Science), MAGYAR TUDOMÁNY 757-765 (June, 2004). 


\section{A. Fundamental Questions in Criminalistics}

As the author sees them, the main questions in criminalistics serve as basic principles, since, as already noted, without answering them we cannot claim that we correctly know the relevant facts, the historical past, and the facts of the case to be considered. The principal risk involved is possible "judicial murder", ${ }^{21}$ which is to be avoided and prevented by all means in any application of the law.

A close look at the seven relevant questions and the answers they require reveals that the answer to the seventh question, WHY, may be omitted. We cannot skip the WHAT question, as no correct final resolution can be made without an answer to that, not even at the more advanced and highly principled trial stage. Certain types of questions must, of necessity, be answered during the investigation stage. There is no way to circumvent them, as these basic tasks and responsibilities cannot be passed on to the court, which does not have the instruments, the apparatus, methodology, etc. to perform them.

The WHY question is relevant for several reasons, including prescription, alibi, legal regulations to be applied, etc. The HOW question may have outstanding significance in determining the basic cases and classifications, and it may also affect the answer to the WHY question. Court decisions may be made without knowledge of the motive or cause, that is, an answer to the WHY question, which is, thus, not essential. But answers to the questions of WHO and WITH WHOM are by all means obligatory. ${ }^{22}$ Thus, these essential questions constitute the foundation of the ranked pyramid of seven questions. On account of their outstanding significance, one might, ironically, call them the "top" questions.

The questions of WHERE, WHEN and HOW are important and need to be answered, but they are not always of the nature of conditio sine qua non. Nor is it absolutely necessary to answer the WHY question. It appears to be much more like a supplementary question, conducive to the investigation process, an effort at answering the rest of the questions, especially the questions of WHO and WITH WHOM.

\footnotetext{
${ }^{21}$ For a detailed discussion of its significance, see Adél Handrik, A justizmordok okai-tévedési források a büntetöeljárásban (Causes of Judicial Murders-Sources of Error in Criminal Procedure), BELÜGYI SZEMLE 41-63 (Sept., 2011).

${ }^{22}$ The methodology of composing profiles emerged at the end of the 20th century in order to aid developing answers to the WHO question. See Gábor Kemény, A profilalkotás (Composing Profiles), BELÜGYI SZEMLE 3-20 (Mar., 1999).
} 


\section{B. Traces and/or Material Remains Are Left Behind in Every Criminal Act}

If this principle was not laid down, if we did not believe in it, then the detection, prosecution and investigation of criminal acts would become pointless. It would be senseless to search for anything if it vanished without a trace, as if it never existed, as if nothing happened at all.

An element of this principle is the principle of theoretical exchange, as it has been formulated in the technical literature. ${ }^{23}$ The principle means that every contact between two persons or objects is accompanied by mutual exchange. The exchange of material remains may be of microscopic dimensions, imperceptible to the naked eye, but now we have the appropriate technology (magnifying glasses, microscopes, etc.) which enables us to observe, study, and eventually identify them.

It is safe to say that at least the odor of a natural person is exchanged, as material remains, in the commission of a criminal act, as there is no way they can prevent it. Attempts are sometimes made to cover them (e.g., the scene is sprayed with pepper), but then those attempts leave behind their own traces and material remains, which can be located and identified.

Material remains are almost like partisans - they are all over the place, all the time, sometimes found in the most unexpected locations, ${ }^{24}$ they persevere, and are incredibly resistant. They are indestructible and they have "a story to tell you about the past", that is, they are capable of identification. According to the technical literature, (the smallest amount of) ubiquitous material remains may assist the conceptual reconstruction of the act and the sequence of events, they may be classified, and they also make unique identification possible. $^{25}$

\footnotetext{
${ }^{23}$ The principle is not new. E. Locard formulated it about a hundred years ago in the French technical literature, cf. his A Manuel de Technique Polciére (Payot, Paris 1923).

${ }^{24}$ According to a witty saying in the technical literature, "there is no such thing as a traceimpoverished scene, only investigators with poor imaginations." Let me make it a little more accurate by proposing that we take traces to also mean material remains, as such always emerge at the scene of a criminal act, and that by the "poverty of imagination" we mean the detective or "path finder" lacking sufficient expertise (and instruments). (Possible synonyms of the witticism above may include these: "Crime scenes can talk to you if you know how to listen"; "A crime scene is like an open book-all you need to know is how to read it."

${ }^{25}$ Let me note in passing that it is a mistake to put an equation sign between the process of investigation and the act of demonstration. Géza Finszter constructs expressive groups, the four possible combinations at the intersections of criminal acts, which are easy vs. difficult to detect, and easy vs. difficult to prove. For more detail on this, see Géza Finszter, A kriminalisztika és a változó tételes jog (Forensic Science and the Changing Statutory Law), In Közbiztonság és társadalom (Public Safety and Society), KRIMINOLÓGIAI KÖZLEMÉNYEK 69, 189-199 (Erzsébet Kadlót ed., Magyar Kriminológiai Társaság, Budapest 2011).
} 


\section{The Uniqueness and Identifiability of Persons and Physical Objects}

As stated above, the peak of the pyramid represents identification. It is a basic principle in both theory ${ }^{26}$ and practice that a natural person perpetrator is a unique subject, not to be confused with any other individual. Each such person is a unique biological being without a duplicate on the earth. As the saying in Latin holds, Natura non facit saltum, nature does not make leaps, that is, it never repeats itself. The goal of an investigator is to find the uniquely identifiable perpetrator(s). The principle offers both theoretical and practical support for that.

Physical objects are different. Here, although the main goal and effort are the same, to identify them uniquely on the basis of traces and material remains, this is not always possible, either in theory or in practice. Think, for instance, of mass produced cars, watches, telephones, jewelry, crowbars, etc., which may all be used as tools in the commission of criminal acts, and are, eventually, objects that leave or carry traces.

\section{The Past Is Knowable}

A glance at the doctrines discussed so far leads to the conclusion that the doctrine just mentioned logically needs to be assigned basic priority, as without a belief in the possibility and human capacity of knowing about the past, talk about detection or demonstration is pointless, and recommendations and methods worked out in forensic science would become meaningless. ${ }^{27}$ Forensic methodology is just a tool which may be used in learning about and reconstructing the past, which is never easy, but it has no ontology in itself. It is "only" applied science, which borrows results from other disciplines, shaping them and adapting them to its needs. ${ }^{28}$ In fairness, it must be added that this is no simple task at all, either

\footnotetext{
${ }^{26}$ Cf. Géza Katona, A kriminalisztika azonositás elmélete (The Theory of Identification in Forensic Science), 1 in KriminalisZTIKA (Forensic ScIENCE) 1-2, 71-88 (Endre Bócz ed., Duna Kiadó, Budapest); Zoltán Hautzinger, Az emberi szagok kriminalisztikai azonositása (Forensic Identification of Human Odors), in EMLÉKKÖNYV VARGHA LÁSZLÓ EGYETEMI TANÁR SZÜLETÉSÉNEK 90 (Csaba Fenyvesi, Csongor Herke eds.). évfordulójára (Festschrift for László Vargha on the 90th anniversary of his birthday) PTE ÁJK 79-89 (Pécs 2003); Endre Bócz and Géza Finszter, Kriminalisztika joghallgatóknak (Forensic Science for Students of Law), MAGYAR KÖZLÖNY LAP- ÉS KÖNYVKIADÓ, 44-55 (Budapest); Flórián Tremmel, Csaba Fenyvesi and Csongor Herke, Kriminalisztika tankönyv és atlasz (Textbook and Atlas in Criminalistics), DiAlóG-CAMPUS KIADÓ (Budapest-Pécs 2005), and Kriminalisztika (Criminalistics) 35-44 (2009).

${ }^{27}$ Cf. Géza Finszter, Bizonyitáselméletek a jog világában (Theories of Demonstration in the World of Law), RENDÉSZETI SZEMLE 70-102 (Jul., Aug., 2006).

${ }^{28}$ As an example, consider the story of DNA. Its internal structure was revealed by Watson and Krick in 1950. Then, in 1986, Alec Jeffreys worked out the related forensic methodology, which eventually served the purposes of identification. For their discoveries, the former were awarded the Noble prize; the applied scientist, on the other hand, was (merely) knighted.
} 
regarding its content or its goal. Those who have tried will know.

\section{CONCLUSION}

As overlapping discussions in the preceding two sections indicate, intimate relations hold among the building blocks and principles of the pyramid model. What at first sight might appear to be forensic science "unjustly skinned to the bone", otherwise carries a very clear message, precisely by virtue of its simplicity, for any practitioner or lay observer. The construction of simple models, as simplified sketches of the scene in investigations and demonstrations, contribute to understanding the topics and issues (the act and its perpetrator) and the definition of tactical tasks and goals. ${ }^{29}$ The popular message applies here too-simple is best. At the same time, researchers are interested in theory and/or practice, professionals involved in the application of law, or indeed any reader may take it as encouragement to formulate further building blocks and/or principles.

\footnotetext{
${ }^{29}$ Many people in science and education are familiar with the quote from Albert Szent-Györgyi that "a researcher who is unable to explain something clearly to an eight-year-old child is a bungler at his trade."
} 